\title{
WPŁYW RELIGIJNOŚCl CZŁOWIEKA NA PRZEZWYCIĘŻANIE CHOROBY ALKOHOLOWEJ
}

DOI: http://dx.doi.org/10.12775/TiCz.2020.043

\begin{abstract}
Streszczenie. Aby skutecznie leczyć alkoholizm, należy poznać przyczyny jego powstawania i wszystkie konsekwencje tej choroby. Leczenie powinno obejmować osobę uzależnioną we wszystkich jej wymiarach: fizycznym, psychicznym i duchowym, ponieważ wszystkie one wpływają na postawę i życie każdego człowieka. Najważniejszym jednak wymiarem dla człowieka, decydującym o jego człowieczeństwie, jest wymiar duchowy i związane z nim przeżywanie swojego życia, dlatego tak ważne w wychodzeniu z uzależnienia jest leczenie sfery duchowej. Oznacza to uzdrawianie relacji z Bogiem, z samym sobą i drugim człowiekiem, a to wiąże się z religijnością określaną przez różnorodne przeżycia, postawy, zachowania, dążenie ku dojrzałości wewnętrznej, a w swej istocie jest przyjaźnią z Bogiem i oddawaniem Mu należnej czci.
\end{abstract}

Słowa kluczowe: alkoholizm; choroba; religijność; duchowość; Bóg.

Abstract: The influence of human religiousness on overcoming the alcohol disease. To treat alcoholism effectively, you need to know the cause of its uprising and all the consequences of this disease. An addict treatment should include all its dimensions: physical, mental and spiritual because they all affect attitude and life of every human. However, the most important dimension for a man, decisive for his humanity is spiritual dimension and related to it experiencing your life. That is why treatment of the spiritual sphere is so important to get out of an addiction. It means healing relationship with God, 
with oneself and another human being, this is connected with religiosity, determined by various people experiences, attitudes, behaviors, striving for internal maturity, and in the essence of it there is a friendship with God and giving Him honor.

Key words: alcoholism; illness; religiosity; spirituality; God.

\section{RELIGIJNOŚĆ W ŻYCIU CZłOWIEKA}

W dzisiejszym świecie, w którym zamiast takich wartości, jak: miłość, wolność, dojrzałość, odpowiedzialność, coraz bardziej promowana jest kultura „wyzwolenia”, istnieje potrzeba głębszej refleksji nad tematem religijności w życiu człowieka. Współcześnie obserwuje się spłycanie samego pojęcia religijności i jej roli w życiu człowieka, szczególnie uzależnionego, dlatego wydaje się słuszne wciąż na nowo poruszanie tego tematu.

Już od początku dziejów człowiek uznawał najwyższą i najdoskonalszą Istotę, jaką jest Bóg. W języku łacińskim kult wobec Boga określano słowem religija, dlatego religia to nauka o Bogu oraz głębokie wewnętrzne i zewnętrzne życie człowieka powiązane z Bogiem. Różnorodne działania podejmowane przez człowieka każdego dnia ze względu na Boga, nazywamy religijnością, która wyrażana jest przez akty czci, uwielbienia, prośby, przeproszenia, modlitwy, akty oddania się Bogu ${ }^{1}$.

W Teologii moralnej ks. Stanisława Olejnika religijność opisana jest jako właściwie zajęta postawa głębokiej czci należnej tylko Bogu uobecniającemu się nieustannie w Chrystusie, która okazywana jest w różnych aktach kultu. Postawa taka w chrześcijańskim przeżywaniu rel.........??

Sam Jezus Chrystus, tu na ziemi, szuka „chwały Ojca”, wykonuje różne akty religijne, dając całym swym postępowaniem doskonały przykład i wzór religijności, o której mówi Ewangelia św. Jana², oddaje Ojcu najdoskonalszy hołd, przez krwawą ofiarę na Krzyżu dla zbawienia ludzi, a przez ustanowienie podczas ostatniej wieczerzy bezkrwawej ofiary, ponawianej we Mszy świętej, Jezus Chrystus określa nowy środek i nowe

${ }^{1}$ J. Śledzianowski, Alkoholizm w świetle chrześcijańskich zasad moralnych, Zakroczym 1987, s. 18.

2 Por. J 7,18; 8,50-54. 
formy religijności prowadzące człowieka do zbawienia. Msza święta jest zatem jedyną w ścisłym znaczeniu ofiarą, którą wierzący składają Bogu, a która posiada ścisły, wewnętrzny związek z Chrystusem, ponieważ wyobraża i uobecnia oraz przypomina ofiarę krzyżową.

W ofierze mszalnej rola Jezusa Chrystusa jest szczególna i jedyna, ponieważ jest to Jego ofiara, którą jako pośrednik między Bogiem i ludźmi, jako jedyny Kapłan Nowego Przymierza ofiarowuje Bogu nie tylko samego siebie, ale występuje jako Przedstawiciel całej ludzkości i Głowa Kościoła. Kościół, który jest Mistycznym Ciałem Chrystusa, we Mszy świętej wraz z Chrystusem, Najwyższym Kapłanem, przez Niego, z Nim i w Nim składa wspólną Bogu ofiarę, która stanowi najważniejszą czynność społeczności Kościoła, jest duszą Kościoła, najgłębszym sensem jego istnienia i życia.

Uczestniczenie we Mszy świętej, wielkim darze i szkole miłości Boga i bliźnich rozwija i pogłębia więź nadprzyrodzonej wspólnoty, umacnia wiarę, otwiera człowieka na Boże powołanie i sens życia w wymiarze wieczności, rodzi męstwo oraz cierpliwość na przeciwności losu, uczy miłosierdzia i przebaczenia, szczególnie kiedy uczestniczenie w Eucharystii jest pełne przez przyjęcie Komunii świętej. Zatem branie udziału we Mszy świętej jest wyrazem religijności człowieka³

Religijność to nie tylko Msza święta, w której uczestniczy cała wspólnota religijna, ale również modlitwa indywidualna, tzw. modlitwa pozaliturgiczna, która należy do najczęstszych i najbardziej powszechnych przejawów religijności, ma zasięg ogólnoludzki, szczególnie w religii chrześcijańskiej i ma szczególny charakter, ponieważ człowiek łączy się z Chrystusem w sposób osobowy. Chrystus jest ośrodkiem kultu, bezpośrednim adresatem modlitwy, jest jedynym pośrednikiem między ludźmi i Bogiem, który w Chrystusie objawia się ludziom, idzie ku nim, zbliża się do nich. W modlitwie człowiek oddaje Bogu siebie całego przez uwielbienie Go, dziękczynienie, przebłaganie, prośby oraz każde pobożne wzniesienie myśli do Boga. Modlitwa jest nie tylko wewnętrznym zwróceniem się człowieka ku Bogu, ale również wyraża się na zewnątrz, ogarniając ludzkie ciało przez pewne gesty, ruchy i słowa, stając się środ-

3 Por. S. Olejnik, Teologia moralna, t. 5: Służba Bogu i otwarcie się na świat, Akademia Teologii Katolickiej, Warszawa 1991, s. 17-69 
kiem wyrazu, wspomagając wysiłek w utrzymaniu i rozwoju wewnętrznej żarliwości modlitewnej.

Religijność łączy się ściśle z cnotami teologalnymi, czyli z wiarą, nadzieją i miłością, ponieważ opiera się na nich oraz uwidacznia w sobie ich wyraźny i głęboki wpływ. Wiara daje poznanie Boga, otwiera dostęp do Niego i warunkuje wyrazy czci oddawanej Bogu, z kolei nadzieja przybliża myśl, pragnienie i wysiłek człowieka w zmierzaniu do doskonałego kultu Bożego. Miłość, która jest najwyższą i najważniejszą cnotą, wprowadza należyte odniesienie do Boga, który sam jest miłością i tej miłości oczekuje od człowieka, miłość bowiem usprawnia i oczyszcza ludzką zdolność miłowania, ożywia i pobudza praktykowanie wszystkich cnót ${ }^{4}$.

Ksiądz Tadeusz Ślipko w książce Zarys etyki ogólnej opisuje religijność jako cnotę, która dysponuje człowieka do oddawania Bogu należytej czci. Należy ona do cnót naturalno-teologicznych, do których zalicza się: mądrość - usprawniająca człowieka do poznania Boga; miłość - nakazująca miłować Go jako najwyższe i nieskończone Dobro i Prawdę; nadzieja - pozwalająca człowiekowi mieć pewność, że osiągnie Boga jako swój cel ostateczny ${ }^{5}$.

Wielka Encyklopedia PWN opisuje religijność jako

zinternalizowany aspekt religii. W teologii religijność jest niekiedy traktowana jako cnota polegająca na okazywaniu Bogu należnej mu czci poprzez akty religijne, kult i określony etos; w niektórych nurtach teologicznych (np. w teologii dialektycznej) religijność rozumiana z perspektywy psychologicznej i antropologicznej została przeciwstawiona wierze, Objawieniu i Łasce Bożej. W naukach o religii (religioznawstwo, filozofia religii, psychologia religii, socjologia religii) religijność jest opisywana w kategoriach określonych przeżyć (doświadczenie religijne, mistyka), zachowań i postaw oraz rozwoju psychospołecznego jednostki. Religijność może wpływać integrująco na życie psychiczne i wspierać człowieka na jego drodze ku dojrzałości, niekiedy także wywierać wpływ negatywny (patologia religijności). Dlatego istotną rolę odgrywają kontakty pastoralne i psychologia pastoralna wspierająca tak zwaną religijność otwartą. Religijność jest przedmiotem badań opisowych (fenomenologia religii) oraz empirycznych, m.in. eksperymentalnych, biograficznych, czy kwe-

${ }^{4}$ Por. tamże, s. 17-69.

${ }^{5}$ Por. T. Ślipko, Zarys etyki ogólnej, Kraków 1974, s. 338. 
stionariuszowych. Religia i religijność są również przedmiotem oddziaływań wychowawczych przybierających zorganizowaną formę katechezy bądź nauczania religii, teoretycznie reflektowanych przez katechetykę i pedagogikę religii ${ }^{6}$.

Socjologia religii daje następującą definicję religijności: „Religijność jest to podzielany i spełniany przez grupę ludzi zbiór instytucjonalnych wierzeń, wartości i symboli oraz związanych z nimi zachowań, które wynikają z rozróżnienia rzeczywistości empirycznej i poza empirycznej oraz z przyporządkowania co do znaczenia spraw rzeczywistości empirycznej sprawom rzeczywistości poza empirycznej"7.

W religijności chrześcijańskiej człowiek uwielbia Boga również poprzez kult religijnej czci osób i rzeczy świętych, które w sposób szczególny przynależą do Boga, a które stają się pomocą człowieka w drodze do Boga. Szczególne i wyjątkowe miejsce w śród ludzi naznaczonych znamieniem świętości zajmuje Maryja, Matka Boża, której wyjątkowa godność wypływa ze szczególnego wybrania Bożego, jakim było powołanie do Bożego Macierzyństwa ${ }^{8}$, „odkupiona w sposób wznioślejszy ze względu na zasługi Syna swego i zjednoczona z nim węzłem ścisłym i nierozerwalnym, obdarzona jest tym najwyższym darem i najwyższą godnością, że jest mianowicie Rodzicielką Syna Bożego a przez to najbardziej umiłowaną Córą Ojca i świętym Przybytkiem Ducha Świętego" ". Maryja, jako Boża Rodzicielka, obecna w tajemnicy Chrystusa jest nieustannie obecna również w tajemnicy Kościoła, otaczana szczególną czcią religijną „doznaje od Kościoła czci szczególnej [...] czczona jest pod zaszczytnym imieniem Bożej Rodzicielki, pod której obronę uciekają się w modlitwach wierni we wszystkich swoich przeciwnościach i potrzebach"10. Maryja wolna od wszelkiego grzechu, obdarzona ogromnym bogactwem łaski oraz nieporównywalnym

6 Wielka encyklopedia PWN, Warszawa 2004, s. 244.

7 W. Piwowarski, Religijność miejska $w$ rejonie uprzemysłowionym, Warszawa 1977, s. 22.

${ }^{8}$ Por. S. Olejnik, dz. cyt., s. 75.

${ }^{9}$ Konstytucja dogmatyczna o Kościele, 53, w: Sobór Watykański II, Konstytucje, Dekrety, Deklaracje, Poznań 2002,s. 155.

${ }^{10} \mathrm{KK}$ 66, [w] Sobór Watykański II, dz. cyt., s. 161. 
pięknem duchowym, staje się wzorem do naśladowania dla wszystkich ludzi ${ }^{11}$.

Przedmiotem religijnej czci są również „wyniesieni na ołtarze” na drodze beatyfikacji i kanonizacji ci, którzy odznaczali się praktykowaniem cnót w stopniu heroicznym, niekiedy aż do przelewu krwi. Za ich wstawiennictwem Kościół zanosi publiczne modlitwy do Boga i stawia ich wierzącym na wzór życia chrześcijańskiego. Przez kult świętych myśli i serca wierzących kierują się ku Chrystusowi a przez Niego, w Nim i z Nim ku Bogu.

Religijność wiąże się także z oddawaniem głębokiej czci religijnej każdemu krzyżowi, ponieważ jest on wizerunkiem narzędzia ludzkiego odkupienia i znakiem Zbawiciela. Oddając cześć krzyżowi, człowiek składa hołd i uwielbienie Chrystusowi.

Obrazy i rzeźby religijne również mają pewną wartość w życiu religijnym człowieka. Z religijnością wiąże się także uroczyste przeżywanie dni świątecznych, szczególnie niedzieli, w której Kościół uroczyście czci od czasów apostolskich, tajemnicę paschalną oraz świąt obowiązkowych ${ }^{12}$.

Istotą religijności jest zatem przyjaźń z Bogiem, który uczy mądrej, odpowiedzialnej miłości, dlatego o dojrzałej religijności można mówić wtedy, gdy człowiek żyjąc w przyjaźni z Bogiem, odkrywa i przyjmuje prawdę o sobie, odkrywa sens życia oraz przyjmuje i respektuje właściwe wartości w życiu, żyjąc według przykazań Bożych. W konsekwencji tak przeżywana religijność staje się podstawą wolności, odpowiedzialności wewnętrznej we wszystkich dziedzinach życia. Dlatego prawdziwa religijność nie jest ucieczką od życia i zastępowaniem praktykami religijnymi codziennych obowiązków, ale jest to sztuka życia w dojrzałej miłości popartej praktykowaniem religijnym, jest oparciem dla rozwoju duchowego $^{13}$.

Religijność, tak samo jak rozwój psychiczny człowieka, rozwija się w trzech powiązanych ze sobą nurtach, do których należy po pierwsze: zespół cech wrodzonych, które stopniowo ujawniają się w procesie dojrzewania i ukazują indywidualne cechy charakteru osoby, po drugie:

11 Por. S. Olejnik, dz. cyt., s. 83.

12 Por. tamże, s. 83.

${ }_{13}$ Por. M. Dziewiecki, Nowe przesłanie nadziei, Warszawa 2000, s. 62-105. 
środowisko, w którym człowiek wychowuje się i przebywa, zdolność przyswajania wpływu środowiska fizycznego, społecznego i kulturowego, to znaczy różnego rodzaju działania naśladowcze i po trzecie: zdolność samosterowania zmierzająca do coraz bardziej świadomego zdobywania pełnej dojrzałości osobowej.

Tak jak dla rozwoju psychicznego i kształtowania osobowości człowieka najważniejsze są pierwsze lata życia, tak nie mniej ważne są one dla formowania podstaw wiary i rozwoju religijności ${ }^{14}$. Dziecko przychodzi na świat $\mathrm{w}$ rodzinie, która jest jego naturalnym środowiskiem, a biologiczna więź z rodzicami jest nie tylko naturalnym popędem zwróconym na otrzymywanie pożywienia i opieki podstawowej, ale jest to także psychiczna więź i łączność duchowa dziecka z rodzicami. Duchowa więź z rodzicami prowadzi do stopniowego poczucia pewności, co daje możliwość rozwoju psychicznego i religijnego ${ }^{15}$. Tak więc na rozwój religijności dziecka decydujący wpływ ma zespół czynników występujących w rodzinie i środowisku rodzinnym. Autentyczna religijność rodziców i osób tworzących rodzinę sprzyja właściwemu kształtowaniu religijności, której rozwój nie kończy się wraz z dzieciństwem, ale rozwija się przez całe życie człowieka, dlatego bardzo ważne jest dbanie o jej rozwój na każdym etapie jego życia.

\section{DUCHOWOŚĆ, A UZALEŻNIENIE}

Religijność wpływa na wszystkie wymiary życia człowieka, obejmując go ze wszystkimi jego zaletami, oraz słabościami. Ma ona ogromny wpływ na życie duchowe każdej osoby ludzkiej. Duchowość to niezwykła sfera w człowieku, ponieważ to właśnie ona decyduje o jego człowieczeństwie. Wymiar duchowy niedostępny dla świata zwierząt podobnie jak sfera moralna istnieje tylko w świecie człowieka. Wymiar duchowy ma ogromny wpływ na postawę człowieka wobec różnego rodzaju używek, do których należy między innymi alkohol i wynikające z tego zagroże-

14 Por. F. Adamski, Wychowanie w rodzinie chrześcijańskiej, Kraków 1982, s. $200-201$.

15 Por. A. Misiaszek, Podstawowe prawa dziecka troska duszpasterska, Pelplin 1996, s. 41. 
nia, ponieważ duchowość jest to zdolność człowieka do zrozumienia i doświadczania siebie samego, zdolność do odkrywania sensu ludzkiego życia, którego człowiek nie jest w stanie zrozumieć, bez sięgania do podstawowych wartości duchowych jak: miłość, prawda, odpowiedzialność, wolność.

Wartości duchowe tak jak i normy moralne bronią człowieka przed jego niewłaściwym postępowaniem, oraz krzywdą, jednocześnie ukazując mu drogę optymalnego rozwoju. Ponieważ normy moralne ukazują człowiekowi konkretne zasady postępowania wyrażane poprzez system zakazów, szczególnie Dekalog, a także system pozytywnych wskazań, którymi są dwa przykazania miłości, wartości duchowe ukazują ostateczny sens zasad moralnych oraz kryteria ich tworzenia ze względu na naturę człowieka i na ostateczny sens jego życia, pozwalając przyjmować właściwą hierarchie między życiowymi celami i różnymi dobrami, akceptowanymi jako wartościowe. Tak więc duchowość jest to zdolność odnoszenia się danej osoby do otaczającej rzeczywistości, czyli do Boga i ludzi, do samego siebie, swojego ciała i psychiki.

Rozwój duchowy osiąga swoją pełnię przez wymiar religijny, czyli bliską więź z Bogiem, która prowadzi do odkrywania i przyjmowania pełnej prawdy o sobie. Człowiek, doświadczając Bożej miłości, staje się źródłem wolności i odpowiedzialności we wszystkich dziedzinach życia. Dlatego duchowość możemy nazwać CENTRALNYM SYSTEMEM KIEROWANIA ŻYCIEM ${ }^{16}$.

Człowiek staje się autonomicznym twórcą siebie samego, stanowiąc zarówno o sobie, jak i swoim życiu, jednocześnie opierając się różnego rodzaju negatywnym wpływom oraz presji ze strony środowiska zewnętrznego, jak np. różnych poglądów, mody, emocji, obiegowych przekonań, różnego rodzaju nacisków. Rozwój duchowy człowieka to nieustanny proces $\mathrm{w}$ poszukiwaniu coraz bardziej pogłębionych odpowiedzi na pytanie o istotę człowieka, tego jak żyć w sposób dojrzały i odpowiedzialny, w zgodzie z sobą i drugim człowiekiem, to życie w Bogu i z Bogiem.

Zaniedbanie czy też powierzchowne traktowanie sfery duchowej powoduje utratę dojrzałej postawy wobec siebie, własnego ciała i psychiki,

${ }_{16}$ Por. M. Dziewiecki Rola duchowości w życiu człowieka, https://opoka.org.pl/ biblioteka/T/TS/duchowosc_w_zyciu.html (dostęp: 29.07.2019). 
wobec życia i wolności. Człowiek wybiera wtedy zwykle to, co łatwiejsze, swoje postępowanie podporządkowuje doraźnym potrzebom fizycznym, czy psychicznym a nie określonym wartościom czy świadomym decyzjom. Prowadzi to do trudnych napięć wewnętrznych i konfliktów zewnętrznych, powodując ból i cierpienie ${ }^{17}$. W takich sytuacjach alkohol staje się ogromnie atrakcyjny, gdyż potrafi szybko zmieniać ludzkie emocje, bez zmiany życia czy postępowania

Bardzo często osoby sięgające po alkohol odczuwają swoje życie jako bolesny ciężar i ogromnie tęsknią za doświadczeniem ulgi, dlatego zaczynają traktować alkohol jako środek pomagający w uzyskaniu lepszego samopoczucia, popadając w ten sposób w uzależnienie, czyli alkoholizm, który należy do jednych z najgroźniejszych uzależnień we współczesnym świecie.

Alkohol w życiu takiego człowieka zaczyna zastępować duchowość, staje się coraz bardziej najwyższą wartością, najważniejszą rzeczą, ośrodkiem szczególnej uwagi i obiektem relacji. Całe życie zaczyna się obracać wokół alkoholu, człowiek staje się coraz bardziej egocentryczny, nieodporny na najmniejszą frustrację, nietolerancyjny, pełen lęku, poczucia winy, wstydu, pogrążony w bezwartościowości z poczuciem inności, samotny, pełen oczekiwań. Najważniejszą rzeczą jest zabezpieczenie sobie stałego kontaktu z alkoholem będącego dla osoby uzależnionej najważniejszą rzeczą, ponieważ za pomocą alkoholu podejmowane są próby zarówno opanowania lęku egzystencjalnego, jak i zaspokojenia odczuwania ufności, przyjaźni, znaczenia w życiu, celu, oraz sensu życia.

Alkohol, wypierając wartościowe rzeczy, uniemożliwia rozwój zdolności i talentów, jakie człowiek posiada, pomaga zapełnić życiową pustkę $^{18}$. Uzależnienie to jest całkowitym zaprzeczeniem trzeźwości, jest zaprzeczeniem życia w prawdzie, miłości i wolności, dotyka ono nie tylko osobę nadużywającą alkohol, ale również całą rodzinę, która zaczyna ukrywać przed otoczeniem problem choroby alkoholowej żyjąc w świecie iluzji i zakłamania tak jak osoba uzależniona. Choroba alkoholowa niszczy przede wszystkim sferę duchową człowieka uzależnionego, dotyka również osób, z którymi żyje.

17 Por. M. Dziewiecki, Nowe przesłanie nadziei, s. 62-63.

18 Tamże, s. 121. 


\section{ROLA KAPŁANA W LECZENIU OSOBY UZALEŻNIONEJ}

Bardzo ważne $\mathrm{w}$ wychodzeniu $\mathrm{z}$ choroby alkoholowej i trwałym powrocie do trzeźwości jest przede wszystkim leczenie sfery duchowej, przywrócenie człowiekowi utraconego związku z duchowością z którą związane są podstawowe wartości prowadzące człowieka do właściwych relacji w stosunku do rzeczy i osób, do zrozumienia siebie, do odkrywania prawdy o sobie, swoim życiu, do odkrywania i doświadczania Boga. To staje się pomocą w wyeliminowaniu alkoholu jako wartości i najważniejszej rzeczy będącej w centrum życia człowieka uzależnionego. Jednak sama psychologia i oparta tylko na niej terapia nie wystarcza, ponieważ człowiek jest za słaby, aby mógł sam poradzić sobie z nałogiem. Do tego potrzebny jest Pan Bóg, dlatego w leczeniu sfery duchowej nieodzowny jest doradca duchowy, który pomoże w uzdrawianiu relacji człowieka z Bogiem, z samym sobą, ze swoim sumieniem a także $\mathrm{z}$ drugim człowiekiem.

Osoba wychodząca $\mathrm{z}$ uzależnienia ma bowiem trudności w poradzeniu sobie przede wszystkim z przeszłością, w rozliczeniu się z nią, ma głębokie poczucie winy, czyli „grzechu”. To wszystko wiąże się z przebaczeniem, które w swej najgłębszej istocie jest przede wszystkim aktem ufności w nieskończoną Bożą miłość i miłosierdzie. Ufność ta nie jest jednorazowym aktem lecz procesem, który nie może odbywać się samotnie, ale z drugim człowiekiem, którego życie duchowe ma wymiar najgłębszy. Osobą taką jest odpowiednio przygotowany do tego kapłan znający dobrze problem uzależnień, posiadający ukończone kursy i certyfikaty w tym kierunku. Jego rola w leczeniu sfery duchowej jest niezwykle ważna i niewymierna ${ }^{19}$, ponieważ pomaga wyjaśnić, czym jest krzywda, wina, zadośćuczynienie, odpowiedzialność, przebaczenie, nawrócenie. To wszystko realizowane jest w relacji do kochającego i przebaczającego Boga, który tak bardzo bliski człowiekowi jest ukazany w przypowieści o synu marnotrawnym z Ewangelii św. Łukasza.

$\mathrm{W}$ rozliczeniu się z przeszłością potrzebna jest pomoc duszpasterza, który umie słuchać ze spokojem i cierpliwością, rozmawiać bez krytykowania i krzyku, bez wypominania i złości; z prawdziwą ojcowską miłością. Udziela sakramentu pokuty i pojednania mającego uzdrawia-

19 Por. J. Kinney, G. Leaton, Zrozumieć alkohol, Warszawa 1996, s. 223. 
jącą moc i dającego na nowo łaskę dziecka Bożego. Pomaga zrozumieć, że przebaczenie uwalnia od poczucia winy i urazy w stosunku do siebie i innych, które obok strachu są największymi źródłami stresu psychicznego i tak jak strach zużywają bardzo duże zasoby energii, której zostaje wówczas mniej na inne uczucia i przeżycia w życiu. Umożliwia uczenie się nowej postawy wobec własnej cielesności, swojego ciała, które jest najbardziej odczuwaną sferą ludzkiej rzeczywistości. Wskazuje jak należy mądrze kierować sferą cielesną, aby odkryć sens ludzkiego ciała, zająć dojrzałą postawę wobec własnej cielesności, która wiąże się nie tylko $\mathrm{z}$ troską o zdrowie fizyczne, ale również $\mathrm{z}$ rozumieniem zachodzących zmian i procesów fizjologicznych w organizmie a także z zdolnością do dyscypliny i stawiania sobie takich wymagań, aby być panem, a nie sługą swojego ciała, które wraz z duszą stanowi nierozerwalną całość i stanowi o naszym człowieczeństwie Jest niezbędne, aby kochać siebie i innych ludzi miłością prawdziwą, tzn. dojrzałą, odpowiedzialną, wymagającą i czułą - miłością widzialną, wcieloną w rzeczywistość, o której mówi Pan Jezus w Ewangelii.

Kapłan uczy dojrzałej postawy wobec własnego myślenia, szukania prawdy, która wyzwala, uczy poznawać swoje emocje oraz uczucia i to, jak nimi kierować. Uczy dojrzałej wrażliwości moralnej, dojrzałej postawy wobec siebie, Boga i ludzi. Uczy bycia świadomym, że ma się jedno życie i nie należy go zmarnować. Uczy miłości, modlitwy i medytacji, które w swej istocie są wyrazem najgłębszej ufności.

Tak więc kapłan, jako doradca duchowy, staje się nieocenioną i niezbędną pomocą dla osoby dotkniętej chorobą alkoholową na drodze trzeźwości, walczącej o swoje życie, o rodzinę, dzieci, małżeństwo. Jest przewodnikiem w jego drodze do Boga i w budowaniu coraz doskonalszej więzi i przyjaźni z Bogiem.

\section{PROGRAM DWUNASTU KROKÓW PROGRAMEM DUCHOWYM}

W przywracaniu duchowości, która jest niezbędna w wychodzeniu $\mathrm{z}$ uzależnienia i powrocie do życia w trzeźwości pomaga również program 12 kroków. Czym jest Program Dwunastu Kroków? Jest to program, który zawiera w sobie uniwersalne zasady postępowania w sytuacji, kiedy czło- 
wiek znajduje się $\mathrm{w}$ poważnych trudnościach życiowych (uzależnienia, współuzależnienie, popadnięcie w inne formy kryzysu). Jest zbiorem zasad duchowych, które mogą pomóc człowiekowi wyjść z zaklętego kręgu alkoholizmu, stać się człowiekiem zdrowym, szczęśliwym, pełnym radości i pogody ducha oraz pożytecznym dla innych ${ }^{20}$.

Właśnie ten program, który proponują Anonimowi Alkoholicy w przezwyciężeniu choroby alkoholowej jest programem duchowym, obejmującym człowieka w całym jego wymiarze, odnoszący się do Siły Wyższej, jaką jest Bóg, bez którego człowiek nie jest w stanie sobie pomóc. Jeżeli alkoholik chce wyzdrowieć, musi oprzeć się na sile większej niż on sam. Siłą większą od tej, którą posiada człowiek, może być religia i związana z nią religijność wyniesiona ze środowiska, w którym się urodził i wzrastał, a która stanie się pomocą i źródłem dla leczącego się alkoholika.

Swój początek Program Dwunastu Kroków zawdzięcza wspólnocie AA, która powstała w Stanach Zjednoczonych w miasteczku Akron w połowie lat 30. Właśnie tam dwaj alkoholicy Bill Wilson - makler giełdowy, który miał za sobą wiele pobytów w zakładach odwykowych, a terapie nie dawały żadnych rezultatów, oraz chirurg Robert Halbrook Smith, który nie mógł pełnić już swoich obowiązków jako lekarz, zaczęli spotykać się i rozmawiać o swoich problemach. Wspólne spotkania pozwoliły Bilowi i doktorowi Robertowi ukazać własną bezsilność wobec alkoholu i towarzyszące temu przekonanie, że tylko dzięki osobistej więzi z Bogiem można na stałe powrócić do życia w trzeźwości ${ }^{21}$.

Te spotkania i wspólne rozmowy dały początek programowi i wspólnocie AA skupiając dzisiaj ponad milion alkoholików na całym świecie ${ }^{22}$. Program ten pomaga nie tyko alkoholikom, lecz także ich rodzinom korzystającym $\mathrm{z}$ grup samopomocowych oraz służy również w wychodzeniu z innych uzależnień i kryzysów. Osoby uczęszczające na grupy samopomocowe czerpią z tych kroków siłę, wiarę zmieniając siebie i swoje życie odnajdują sens własnego istnienia, odnajdują wiarę w Boga ${ }^{23}$

${ }^{20}$ Por. B. Woronowicz, Samopomoc alkoholików i ich bliskich, w: Nowe przesłanie nadziei, red. M. Dziewiecki, Warszawa 2000, s. 314.

${ }^{21}$ Por. Piotr AA, Wyznanie religijne, a grupa AA, „Zdrój” 6 (2006), s. 20-22.

${ }^{22}$ Por. M. Dziewiecki, Zagrożeni alkoholem, chronieni miłością, Częstochowa 2007, s. 148.

${ }^{23}$ Por. T. Biedulska, Anonimowi Alkoholicy, Warszawa 2000, s. 12. 
Pierwszym warunkiem wychodzenia $\mathrm{z}$ kryzysu jest uznanie prawdy o sobie i o swoich słabościach, tego, że jest się osobą, która nie potrafi zapanować nad swoimi słabościami, co prowadzi do utraty kontroli nad własnym życiem ${ }^{24}$.

Kolejnym etapem pracy nad sobą według Dwunastu Kroków jest uznanie przez osobę dotkniętą chorobą alkoholową tego, że sama nie poradzi sobie z tym problemem, a powrót do zdrowia w samotności jest niemożliwy i potrzebuje pomocy z zewnątrz, tak więc następnym krokiem, który robi, jest zwrócenie się do Siły Wyższej - Boga i powierzenie jego opiece swojej woli i swojego życia, które do tej pory było kierowane przez alkohol. Oznacza to nowy kierunek życia.

Kolejny stopień programu jest bardzo ważny, ponieważ pomaga w gruntownym, moralnym rozliczeniu się z przeszłością uwalniającym od poczucia winy i lęku, prowadzi do analizy swoich wad charakteru oraz sytuacji, które powodowały strach, ucieczkę od rzeczywistości, uczy tolerancji i zrozumienia dla innych, pomaga zrobić listę osób, które się skrzywdziło łącznie z samym sobą, prowadzi do odkrywania prawdy o sobie, swoim życiu.

Krok piąty z kolei prowadzi do podzielenia się swoimi problemami oraz swoimi wadami przed Bogiem i drugim człowiekiem. Najtrudniejsza jest rozmowa o samym sobie $z$ drugim człowiekiem, ale to prowadzi do wyjścia $\mathrm{z}$ osamotnienia, uczy odwagi, pokory i stawania w prawdzie przed samym sobą, drugim człowiekiem i Bogiem, uwolnienia od poczucia winy i lęku, daje wewnętrzny spokój, który jest bardzo potrzebny na drodze wychodzenia z uzależnienia, czy współuzależnienia.

Kroki szósty i siódmy stanowią kontynuację wewnętrznego oczyszczania, uczą pokory i zaufania wobec Boga oraz przekonania, że z jego pomocą można usunąć wszystkie wady i słabości. Umacniają w nadziei, że przemiana jest możliwa.

Kolejne dwa kroki prowadzą do zadośćuczynienia wszystkim tym osobom, które się krzywdziło, wobec których jest to możliwe, nie zapominając o sobie, uwalniają z pułapki obwiniania innych ludzi za trudności życiowe.

${ }^{24}$ Por. M. Dziewiecki, Nowe przesłanie nadziei, Warszawa 2000, s. 223; J. Kinney, G. Leaton, Zrozumieć alkohol, Warszawa 1996, s. 213. 
Następny krok, dziesiąty, przypomina o nieustannej pracy nad sobą, obserwacji siebie, swojego zachowania, aby to, co się osiągnęło $\mathrm{z}$ wielkim trudem, nie zostało zaprzepaszczone. Pozwala żyć w prawdzie i zachować pokój wewnętrzny, który jest tak bardzo ważny na drodze trzeźwości.

Krok jedenasty uczy budowania coraz bardziej doskonałej więzi z Bogiem, przez modlitwę i medytację, pomaga w dalszym rozwoju duchowym, pomaga żyć w prawdzie. Dzięki temu uzależniony czy współuzależniony może na co dzień poznawać wolę Bożą i mieć siłę do jej wypełnienia.

Krok dwunasty jest uwieńczeniem wszystkich kroków i mówi o dzieleniu się z innymi swoją siłą i nadzieją, jest niesieniem pomocy innym dotkniętym chorobą alkoholową bez oczekiwania czegokolwiek w zamian. Krok ten pomaga samemu alkoholikowi i jego najbliższym w trwaniu w trzeźwości, w życiu w prawdzie ${ }^{25}$, o której czytamy w Ewangelii św. Jana 8,32. Te słowa Jezusa zawarte w Ewangelii Jana - „Poznacie prawdę, a prawda was wyzwoli...”, są jednymi z najważniejszych słów. Są one bowiem istotą ludzkiego bytu, wewnętrznej jego przestrzeni. Określają one wielkość duszy ludzkiej, godności człowieka.

Każdy powinien nieustannie szukać w życiu prawdy, rozwijać się wewnętrznie, by móc to osiągać. Tylko w taki sposób możliwe jest dążenie ku życiu wyzwolonemu, nieskrępowanemu, właściwemu, dlatego ażeby wyjść z zaklętego kręgu alkoholizmu i żyć w trzeźwości, należy przede wszystkim odkrywać prawdę o sobie, o swoim życiu, odkrywać Boga jako miłującego Ojca, jego nieskończoną miłość do nas.

Owocem realizacji tego Programu jest osobista przemiana i przebudzenie duchowe, które sprawia, że osoba uzależniona czy też współuzależniona podejmuje radykalnie nowy styl życia Czyni go też zdolnym do tego by nieść nadzieję i pomoc innym ludziom ${ }^{26}$. W tym właśnie pomaga Program Dwunastu Kroków, stając się najskuteczniejszą pomocą i narzędziem dla człowieka, który pragnie pokonywać swoje słabości, odkrywać

25 Por. M. Dziewiecki, Nowe przesłanie nadziei, s. 223-224; J. Kinney, G. Leaton, dz. cyt., s. 214-215; Służby Światowe Anonimowych Alkoholików, Anonimowi Alkoholicy, Warszawa 2003, s. 50-90.

${ }^{26}$ Por. M. Dziewiecki, Zagrożeni alkoholem, chronieni miłością, Częstochowa 2007, s. $148-149$. 
wiarę, żyć w prawdzie i miłości do Boga, oraz ludzi , który pragnie stawać się najpiękniejszą wersją siebie.

Program Dwunastu Kroków, jak opisuje je ks. Marek Dziewiecki, to rodzaj specjalistycznych rekolekcji. Program ten opiera się na Słowie Bożym i jest tak skonstruowany, że każdy, kto chce zmieniać swoje życie i rozwijać się duchowo, może go realizować, ponieważ jest programem niepowtarzalnych możliwości rozwoju, prowadzi nie tylko do odkrywania wiary, lecz także do życia w prawdzie, miłości i wolności dzieci Bożych, a to wiąże się z prawdziwą religijnością, która opisana jest w pierwszym punkcie $^{27}$.

\section{PODSUMOWANIE}

Rozwój duchowy człowieka oparty na religijności, której istotą jest przyjaźń z Bogiem i życie w Bogu, potrzebny jest w życiu każdej osoby bez względu na jakim etapie swego życia się znajduje- czy jest to dziecko, czy człowiek dojrzały, czy też osoba starsza. Ukazany w artykule - wpływ religijności człowieka na wychodzenie z choroby alkoholowej nie wyczerpuje wszystkich zagadnień dotyczących tego tematu, lecz tylko go sygnalizuje. Celem artykułu było zwrócenie uwagi na niewymierną wartość religijności w życiu każdego człowieka, szczególnie jak ważną rolę odgrywa religijność w życiu osoby uzależnionej od alkoholu i jego rodziny stając się pomocą w drodze do trzeźwości i przemiany całego życia.

\section{BIBLIOGRAFIA}

Adamski F., Wychowanie w rodzinie chrześcijańskiej, Wydawnictwo Apostolstwa Modlitwy, Kraków 1982.

Biedulska T., Anonimowi Alkoholicy, Wydawnictwo Interlibro, Warszawa 2000.

Biblia Tysiąclecia, Pismo Święte Starego i Nowego Testamentu, Pallottinum, Poznań-Warszawa 1971.

Dziewiecki M., Nowe przesłanie nadziei, PARPA, Warszawa 2000.

Dziewiecki M., Zagrożeni alkoholem, chronieni miłością, Wydawnictwo Pomoc, Częstochowa 2007.

${ }^{27}$ Por. M. Dziewiecki, Droga zwycięzców. 12 kroków nie z tej ziemi, Częstochowa 2016, s. 213. 
Dziewiecki M., Droga zwycięzców. 12 kroków nie z tej ziemi, Wydawnictwo Święty Paweł, Częstochowa 2016.

Dziewiecki M. Rola duchowości w życiu człowieka, https://opoka.org.pl/biblioteka/T/TS/ duchowosc_w_zyciu.html (dostęp: 29.07.2019).

Kinney J., Leaton G., Zrozumieć alkohol, PARPA, Warszawa 1996.

Konstytucja dogmatyczna o Kościele Lumen gentium, Poznań 2002.

Misiaszek A., Podstawowe prawa dziecka troska duszpasterska, Wydawnictwo Bernardinum, Pelplin 1996.

Olejnik S., Teologia moralna, t. 5: Stużba Bogu i otwarcie się na świat, Akademia Teologii Katolickiej, Warszawa 1991.

Piotr AA, Wyznanie religijne, a grupa AA, „Zdrój” 6 (2006), s. 20-22.

Piwowarski W., Religijność miejska $w$ rejonie uprzemysłowionym, Wydawnictwo WIĘŹ, Warszawa 1977.

Śledzianowski J., Alkoholizm w świetle chrześcijańskich zasad moralnych, Ośrodek Apostolstwa Trzeźwości, Zakroczym 1987.

Ślipko T., Zarys etyki ogólnej, Wydawnictwo WAM, Kraków 1974.

Służby Światowe Anonimowych Alkoholików, Anonimowi Alkoholicy, Fundacja Biuro Służby Krajowej Anonimowych Alkoholików w Polsce Warszawa 2003.

Wielka Encyklopedia Powszechna, Wydawnictwo Naukowe PWN, Warszawa 2004.

Woronowicz B., Samopomoc alkoholików i ich bliskich, w: Nowe przesłanie nadziei, red. M. Dziewiecki, PARPA, Warszawa 2000. 